\title{
Pengaruh Faktor Fundamental Pada Nilai Perusahaan Manufaktur Sektor Basic Industry And Chemical Di Bursa Efek Indonesa
}

\author{
Rosnita Novalia ${ }^{1}$, Aljufri ${ }^{2}$ \\ Fakultas Ekonomi Universitas Lancang Kuning Pekanbaru \\ Eri_jufri@yahoo.co.id
}

\begin{abstract}
This study aims to determine the influence of fundamental factors (EPS, DER, CR, TATO and size of the Company) on the value of the manufacturing company Basic Industry and Chemicals sector in Indonesia Stock Exchange 2011-2014 period. The population in this study are all companies Manufacturing Basic Industry and Chemicals sectors listed on the Stock Exchange the period 2011 to 2014, amounting to 63 companies While the sample was determined by purposive sampling method in order to obtain as many as 29 companies sampled. The analytical method used is multiple linear regression analysis with SPSS 17.00. Before the data were analyzed, performed classical assumption of the data. Statistical tests showed that (1) Taken together variable EPS, DER, CR, TATO, and company size effect on firm value (PBV) (2) Earning Per Share (EPS) effect on firm value (3) Debt to Equity ratio (DER) effect on firm value (4) Current ratio (CR) effect on the value of the company (5) Total Asset Turn Over (TATO) effect on the value of the company (6) the size effect on the company's corporate value.
\end{abstract}

Keywords: Fundamentals, Earnings Per Share, Debt to Equity Ratio, Current Ratio, Total Asset Turn Over, Company Size, Price to Book Value, Value Company

Nilai perusahaan merupakan kondisi tertentu yang telah dicapai oleh suatu perusahaan sebagai gambaran dari kepercayaan masyarakat terhadap perusahaan setelah melalui suatu proses kegiatan selama beberapa tahun. Dengan semakin ketatnya persaingan dalam dunia bisnis dan situasi ekonomi sekarang yang tidak menentu, membuat perusahaan harus memiliki kemampuan untuk bertahan. Salah satu upaya yang dapat dilakukan adalah dengan meningkatkan nilai perusahaan. Dengan meningkatnya nilai perusahaan adalah sebuah prestasi, yang sesuai dengan keinginan para pemiliknya, karena dengan meningkatkan nilai perusahaan, maka kesejahteraan pemiliknya juga akan meningkat. Hal ini tentu saja akan meningkatkan minat investor untuk membeli saham perusahaan.

Dalam mengambil keputusan, investor melakukan penilaian terhadap nilai perusahaan. salah satu cara yang dilakukan dengan memperhatikan faktor-faktor internal perusahaan, atau yang lebih sering dikenal dengan faktor fundamental yaitu faktor yang berkaitan langsung dengan kinerja suatu perusahaan. Analisis fundamental memfokuskan pada laporan keuangan perusahaan yang memberikan dasar teoritis perhitungan nilai intrinsik yang dapat ditentukan berdasarkan faktor fundamental perusahaan. Walaupun disadari bahwa faktor-faktor fundamental sangat luas dan kompleks cakupannya, tidak saja mencakup kondisi internal perusahaan (basic financial), tetapi juga kondisi fundamental makro ekonomi yang berada diluar kendali perusahaan.

Penelitian ini merupakan pengembangan dari penelitian yang dilakukan oleh Wedana (2013) dengan mengikuti salah satu saran untuk penelitian selanjutnya, dimana Wedana menyarankan untuk menambahkan variabel dari segi kemampuan perusahaan dalam memenuhi kewajiban-kewajiban jangka pendek (rasio likuiditas) dan kemampuan perusahaan dalam menggunakan sumber daya-sumber daya yang dimiliki (rasio aktivitas). Berdasarkan hal tersebut, faktor fundamental yang dipakai dalam penelitian 
ini antaralain earning per share (EPS), debt to equity ratio (DER), Current Ratio (CR), Total Asset Turnover (TATO) dan Ukuran Perusahaan.

Rasio earning per share (EPS) yang menggambarkan profitabilitas perusahaan yang tergambar pada setiap lembar saham. Rasio debt to equity ratio (DER) digunakan untuk melihat perbandingan antara hutanghutang dan ekuitas dalam pendanaan perusahaan yang menunjukkan kemampuan modal sendiri perusahaan untuk memenuhi seluruh kewajibannya. Rasio current ratio (CR) yang memberikan gambaran tentang kemampuan perusahaan dalam memenuhi kewajiban jangka pendeknya, dimana semakin besar persentase CR maka perusahaan memiliki tingkat likuiditas yang baik sehingga akan memberikan persepsi positif terhadap kondisi perusahaan serta akan meningkatkan nilai perusahaan dimata investor. Rasio Total Asset Turnover (TATO) ini untuk mengukur efektivitas perusahaan dalam mengoperasikan dana yang dimiliki. Ukuran perusahaan (firm size) dalam penelitian ini dinyatakan dengan total aktiva, dengan semakin besar total aktiva perusahaan maka akan semakin besar pula ukuran perusahaan itu. Dalam penelitian ini, ukuran perusahaan akan dinilai dengan log natutal $(\log n)$ dari total aktiva.

Dalam penelitian ini menggunakan perusahaan manufaktur khususnya pada sektor industry dasar dan kimia (basic industry and chemicals). Perusahaan basic industry and chemicals tergolong ke dalam 8 subsektor, diantaranya adalah Semen; Keramik, Kaca dan Porselen; Logam dan sejenisnya; Kimia; Plastik dan Kemasan; Pakan Ternak; Kayu dan Pengolahannya; Pulp dan Kertas. Alasan obyek penelitian ini pada perusahaan industry dasar dan kimia (basic industry and chemicals) karena perusahaan tersebut hampir tdak terpengaruh oleh fluktuasi perekonomian melainkan perusahaan tersebut akan tetap eksis dan bertahan, disebabkan oleh produk yang dihasilkannya. Karena permintaan akan produk yang dihasilnya perusahaan tersebut akan tetap stabil walaupun ada suatu penurunan tidak berpengaruh terhadap aktivitas perusahaan dalam menghasilkan laba yang optimal.

Nilai perusahaan merupakan persepsi investor terhadap perusahaan, yang sering dikaitkan dengan harga saham (Sujoko dan Soebiantoro;2007). Nilai perusahaan merupakan harga yang bersedia dibayar oleh calon pembeli apabila perusahaan tersebut dijual, semakin tinggi nilai perusahaan semakin besar kemakmuran yang akan diterima oleh pemilik perusahaan (Husnan dan Pudjiastuti;2007;7).

Menurut Jogiyanto $(2008 ; 89)$ faktorfaktor fundamental perusahaan adalah faktor-faktor yang berhubungan dengan kondisi perusahaan yang meliputi kondisi manajemen, organisasi, sumber daya manusia dan keuangan perusahaan yang tercermin dalam kinerja perusahaan. Menurut Horne and Wachowicz (2012;163) bahwa : to evaluate the financial condition and performance of a firm, the financial analyst needs certain yardstick. The yardstick frecuently used is a ratio, index, relating two pieces of financial data of two each other. Dari pendapat ini dapat dikatakan bahwa untuk mengevaluasi kondisi perusahaan dan kinerjanya, dapat digunakan rasio keuangan, indeks dan perbandingan data keuangan perusahaan antara tahun bersangkutan dengan tahun sebelumnya.

\section{METODE}

Populasi yang digunakan pada penelitian ini adalah seluruh perusahaan Manufaktur sektor Basic Industry and Chemicalsyang listing di BEI yang berjumlah 63 perusahaan. Teknik sampling yang digunakan dalam penelitian ini adalah purposive sampling yaitu sampel yang dipilih berdasarkan atas adanya tujuan dan pertimbangan tertentu. Berdasarkan teknik pengambilan sampel diatas, maka diperoleh sampel dalam penelitian ini yaitu berjumlah 29 (dua puluh sembilan) perusahaan Manufaktur sektor Basic industry and chemicals di Bursa Efek Indonesia.

p.ISSN: $2407-800 X \quad$ e.ISSN: 2541-4356 


\section{HASIL}

Berdasarkan hasil analisis regresi linear, maka terbentuk persamaan regresi untuk model penelitian sebagai berikut :

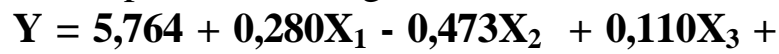
$\mathbf{0 , 9 2 3 X}_{4}+\mathbf{0 , 4 7 3 X _ { 5 }}$

Dari model regresi diatas maka dapat diambil kesimpulan bahwa :

1. Pengaruh variabel EarningPer Share (EPS), Current Ratio (CR), Total Asset Turn Over (TATO) dan Ukuran Perusahaan terhadap PBV adalah positif. Sedangkan pengaruh variabel Debt To Equity Ratio (DER) terhadap PBV adalah negatif.

2. Besarnya konstanta sebesar 5,764 berarti jika variabel X (EPS, DER, CR, TATO dan Ukuran Perusahaan) dianggap konstan, maka besarnya PBV adalah sebesar 5,764.

3. Koefisien regresi $X_{1}$ untuk variabel Earning Per Share (EPS) bernilai positif 0,280 . Artinya bahwa pengaruh variabel EPS searah dengan peningkatan PBV. Angka 0,280 menyatakan bahwa setiap peningkatan pada variabel EPS satu satuan, maka akan terjadi peningkatan pada PBV sebesar 0,280.

4. Koefisien regresi $X_{2}$ untuk variabel Debt To Equity Ratio (DER) bernilai negatif 0,473 . Artinya bahwa pengaruh variabel DER tidak searah dengan peningkatan PBV. Angka 0,473 menyatakan bahwa setiap peningkatan pada variabel DER satu satuan, maka akan terjadi penurunan pada PBV sebesar 0,473.

5. Koefisien regresi $X_{3}$ untuk variabel Current Ratio (CR) bernilai positif 0,110 . Artinya bahwa pengaruh variabel CR searah dengan peningkatan PBV. Angka 0,110 menyatakan bahwa setiap peningkatan pada variabel CR satu satuan, maka akan terjadi peningkatan pada PBV sebesar 0,110.

6. Koefisien regresi $\mathrm{X}_{4}$ untuk variabel Total Asset Turn Over (TATO) bernilai positif 0,923 . Artinya bahwa pengaruh variabel TATO searah dengan peningkatan PBV. Angka 0,923 menyatakan bahwa setiap peningkatan pada variabel TATO satu satuan, maka akan terjadi peningkatan pada PBV sebesar 0,923.

7. Koefisien regresi $X_{5}$ untuk variabel Ukuran Perusahaan bernilai positif 0,473 . Artinya bahwa pengaruh variabel Ukuran Perusahaan searah dengan peningkatan PBV. Angka 0,473 menyatakan bahwa setiap peningkatan pada variabel Ukuran Perusahaan satu satuan, maka akan terjadi peningkatan pada PBV sebesar 0,473 .

\section{Hasil Uji F (Simultan)}

Pengujian hipotesis dengan menggunakan uji F statistik dilakukan dengan membandingkan nilai $F_{\text {hitung., }}$ Hasil tersebut menunjukkan bahwa nilai $F_{\text {hitung }}(8,382)$ lebih besar dari nilai $\mathrm{F}_{\text {tabel }}(2,453)$ dengan nilai signifikan lebih kecil dari 0,05 (0,000). Maka hipotesis pertama dalam penelitiian ini diterima, bahwa variabel EPS, DER, CR, TATO dan Ukuran Perusahaan secara bersama-sama berpengaruh signifikan terhadap Nilai Perusahaan (PBV) perusahaan manufaktur sektor Basic Industry and Chemicals di Bursa Efek Indonerisa periode 2011-2014.

\section{Hasil Uji t (Parsial)}

Uji t (parsial) digunakan untuk mengetahui atau mengukur pengaruh variabel independen terhadap variabel dependen. Analisis dilakukan dengan melihat nilai $t_{\text {tabel }}$ dibandingkan dengan nilai $t_{\text {hitung }}$ dari hasil output SPSS

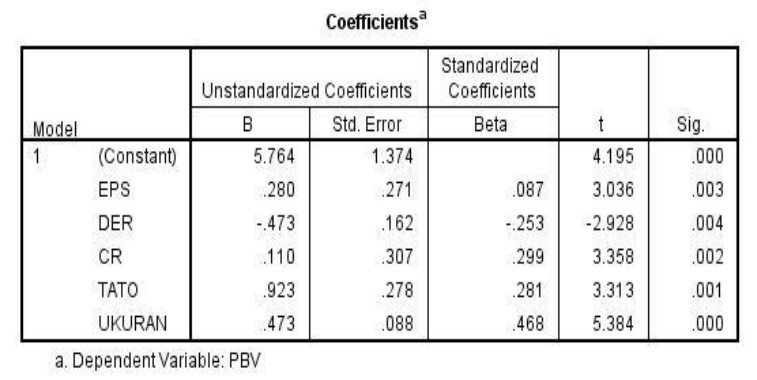

Sumber : Olah Data SPSS, 2016

p.ISSN: 2407-800X

e.ISSN: $2541-4356$ 
Uji t dilakukan pada taraf alpha 0,05 (5\%), dimana pengaruh sangatlah signifikan apabila menghasilkan nilai signifikan $\leq 0,05$

Hasil uji $t$ menunjukkan bahwa varibael EPS, CR, TATO dan Ukuran Perusahaan berpengaruh positif dan siginifikan pada nilai perusahaan, sedangkan DER berpengaruh negatif dan signifikan terhadap nilai perusahaan.

\section{Koefisien Determinasi}

Koefisien determinasi merupakan besaran yang menunjukan besarnya variasi variabel dependen (Nilai Perusahaan diproksikan dengan PBV) yang dapat dijelaskan oleh variabel independen (EPS, DER, CR, TATO dan Ukuran perusahaan). Nilai koefisien determinasi ditentukan dengan nilai adjusted $R$ square

\begin{tabular}{l}
\begin{tabular}{|l|c|r|c|c|c|}
\hline Model Summary \\
\hline 1 & $R$ & R Square & $\begin{array}{c}\text { Adjusted R } \\
\text { Square }\end{array}$ & $\begin{array}{c}\text { Std. Error of } \\
\text { the Estimate }\end{array}$ & $\begin{array}{c}\text { Durbin- } \\
\text { Watson }\end{array}$ \\
\hline
\end{tabular} \\
\hline
\end{tabular}

Sumber : Hasil output SPSS,2016

Nilai adjusted $R$ square adalah 0,724 yang artinya bahwa kemampuan variasi variabel independen yaitu variabel EPS, DER, CR, TATO dan Ukuran perusahaan dalam menjelaskan variasi dari variabel dependen yaitu nilai perusahaan yang diproksikan dengan PBV adalah sebesar $72,4 \%$ dan sisanya dijelaskan oleh variabel-variabel independen lain.

\section{PEMBAHASAN}

Hipotesis kedua dalam penelitian ini adalah Diduga bahwa Earning Per Share (EPS) berpengaruh terhadap Nilai Perusahaan (PBV) pada perusahaan manufaktur sektor Basic Industry and Chemicals di Bursa Efek Indonesia. Dari hasil analisis diperoleh bahwa EPS berpengaruh positif dan signifikan terhadap Nilai Perusahaan (PBV) perusahaan manufaktur sektor Basic Industry and Chemicals di Bursa Efek Indonesia. Koefisien regresi untuk variabel EPS bernilai positif, yang menunjukkan bahwa pengaruh variabel
EPS searah dengan variabel nilai perusahaan (PBV). Hasil penelitian ini sejalan dengan penelitian yang dilakukan oleh Sukaenan (2015) bahwa EPS berpengaruh terhadap nilai perusahaan, namun tidak sejalan dengan penelitian yang dilakukan oleh Wedana (2014).

Earning per share merupakan rasio dari laba bersih terhadap jumlah lembar saham atau pendapatan yang diperoleh dalam satu periode untuk setiap lembar saham yang beredar. Laba merupakan alat ukur utama kesuksesan suatu perusahaan, karena itu para pemodal seringkali memusatkan perhatian pada besarnya earning per share dalam melakukan analisis saham. Hal ini tentu saja akan meningkatkan nilai perusahaan.

Hipotesis ketiga dalam penelitian ini adalah Diduga bahwa Debt To Equity Ratio (DER) berpengaruh terhadap Nilai Perusahaan (PBV) pada perusahaan manufaktur sektor Basic Industry and Chemicals di Bursa Efek Indonesia. Dari hasil analisis diperoleh bahwa DER berpengaruh negatif dan signifikan terhadap Nilai Perusahaan (PBV) perusahaan manufaktur sektor Basic Industry and Chemicals di Bursa Efek Indonesia. Koefisien regresi untuk variabel DER bernilai negatif, yang menunjukkan bahwa pengaruh variabel EPS tidak searah dengan variabel nilai perusahaan (PBV). Hasil penelitian ini sejalan dengan penelitian yang dilakukan oleh Siahaan (2012) dan Sukaenan (2015) bahwa DER berpengaruh terhadap nilai perusahaan, namun tidak sejalan dengan penelitian yang dilakukan oleh Wedana (2014) dan Anzlina (2013).

\section{Debt to Equity Ratio (DER)} merupakan perbandingan antara total hutang dengan total modal sendiri (ekuitas). Debt to Equity Ratio menunjukkan bagian dari setiap rupiah modal sendiri yang dijadikan jaminan untuk keseluruhan utang. DER menjadi salah satu ukuran yang mencermikan faktor resiko yang dihadapi investor. Semakin tinggi tingkat DER akan mengakibatkan resiko financial perusahaan semakin tinggi. Investor cenderung memilih saham dengan DER yang rendah

p.ISSN: $2407-800 X \quad$ e.ISSN: 2541-4356 
Hipotesis keempat dalam penelitian ini adalah Diduga bahwa Current Ratio (CR) berpengaruh terhadap Nilai Perusahaan (PBV) pada perusahaan manufaktur sektor Basic Industry and Chemicals di Bursa Efek Indonesia. Dari hasil analisis diperoleh bahwa CR berpengaruh positif dan signifikan terhadap Nilai Perusahaan (PBV) perusahaan manufaktur sektor Basic Industry and Chemicals di Bursa Efek Indonesia. Koefisien regresi untuk variabel CR bernilai positif, yang menunjukkan bahwa pengaruh variabel $\mathrm{CR}$ searah dengan variabel nilai perusahaan (PBV). Hasil penelitian ini sejalan dengan penelitian yang dilakukan oleh Anzlina (2013) bahwa CR berpengaruh terhadap nilai perusahaan, namun tidak sejalan dengan penelitian yang dilakukan oleh Nugroho (2012).

Current ratio merupakan rasio yang digunakan untuk mengukur kemampuan perusahaan dalam membayar kewajiban jangka pendek atau hutang yang segera jatuh tempo pada saat ditagih secara keseluruhan. Current ratio yang semakin tinggi menunjukkan bahwa perusahaan dalam memenuhi hutang jangka pendeknya semakn tinggi yang berarti kondisi perusahaan baik. Hal ini menunjukkan tingkat kepercayaan investor yang meningkat dan ini akan memberikan kesempatann perusahaan untuk berkembang sehingga dapat meningkatkan harga dan jumlah saham perusahaan yang mengindikasikan meningkatnya nilai perusahaan.

Hipotesis kelima dalam penelitian ini adalah Diduga bahwa Total Asset Turn Over (TATO) berpengaruh terhadap Nilai Perusahaan (PBV) pada perusahaan manufaktur sektor Basic Industry and Chemicals di Bursa Efek Indonesia. Dari hasil analisis diperoleh bahwa TATO berpengaruh positif dan signifikan terhadap Nilai Perusahaan (PBV) perusahaan manufaktur sektor Basic Industry and Chemicals di Bursa Efek Indonesia. Koefisien regresi untuk variabel TATO bernilai positif, yang menunjukkan bahwa pengaruh variabel TATO searah dengan variabel nilai perusahaan (PBV). Hasil penelitian ini sejalan dengan penelitian yang dilakukan oleh Alivia (2013) bahwa TATO berpengaruh terhadap nilai perusahaan, namun tidak sejalan dengan penelitian yang dilakukan oleh Anzlina (2013).

\section{Total Asset Turn Over (TATO)} adalah rasio antara penjualan dengan total aktiva yang digunakan untuk mengukur efisiensi perusahaan secara keseluruhan. Jika laba perusahaan meningkat maka harga saham akan meningkat. Harga saham yang tinggi akan berpengaruh terhadap peningkatan nilai perusahaan yang tercermin dalam Price Book Value. Hal ini tentu saja akan meningkatkan kepercayaan investor untuk menanamkan dananya dalam bentuk saham dan ini akan memberikan kesempatan perusahaan untuk berkembang sehingga dapat meningkatkan harga dan jumlah saham perusahaan.

Hipotesis keenam dalam penelitian ini adalah Diduga bahwa Ukuran Perusahaan berpengaruh terhadap Nilai Perusahaan (PBV) pada perusahaan manufaktur sektor Basic Industry and Chemicals di Bursa Efek Indonesia. Dari hasil analisis diperoleh bahwa Ukuran Perusahaan berpengaruh positif dan signifikan terhadap Nilai Perusahaan (PBV) perusahaan manufaktur sektor Basic Industry and Chemicals di Bursa Efek Indonesia. Koefisien regresi untuk variabel Ukuran Perusahaan bernilai positif, yang menunjukkan bahwa pengaruh variabel Ukuran Perusahaan searah dengan variabel nilai perusahaan (PBV). Hasil penelitian ini tidak sejalan dengan penelitian yang dilakukan oleh Dewi (2013). Dalam penelitiannya Dewi menyatakan bahwa ukuran perusahaan tidak berpengaruh terhadap nilai perusahaan.

Ukuran perusahaan menunjukkan jumlah pengalaman dan kemampuan tumbuhnya suatu perusahaan yang mengindikasikan kemampuan dalam mengelola tingkat resiko investasi yang diberikan para stakeholder untuk meningkatkan kemakmuran mereka. Ukuran perusahaan yang besar akan memiliki prospek yang baik, hal ini tentu akan direspon positif oleh para investor sehingga akan berpengaruh pada peningkatan harga saham. Peningkatan harga saham berarti pula peningkatan nilai perusahaan. 


\section{SIMPULAN}

Penelitian ini bertujuan untuk menguji pengaruh faktor fundamental (EPS, DER, CR, TATO dan ukuran perusahaan) terhadap nilai perusahaan manufaktur sektor Basic Industry and Chemicals di Bursa Efek Indonerisa periode 2011-2014. Kesimpulan yang diperoleh dari hasil penelitian yaitu: Variabel EPS, DER, CR, TATO dan Ukuran Perusahaan secara bersama-sama berpengaruh terhadap Nilai Perusahaan (PBV) perusahaan manufaktur sektor Basic Industry and Chemicals di Bursa Efek Indonerisa periode 2011-2014; Variabel Earning Per Share (EPS) berpengaruh positif terhadap Nilai Perusahaan (PBV) perusahaan manufaktur sektor Basic Industry and Chemicals di Bursa Efek Indonerisa periode 2011-2014; Variabel Debt To Equity Ratio (DER) berpengaruh negatif terhadap Nilai Perusahaan (PBV) perusahaan manufaktur sektor Basic Industry and Chemicals di Bursa Efek Indonerisa periode 2011-2014; Variabel Current Ratio (CR) berpengaruh positif terhadap Nilai Perusahaan (PBV) perusahaan manufaktur sektor Basic Industry and Chemicals di Bursa Efek Indonerisa periode 2011-2014; Variabel Total Asset Turn Over (TATO) berpengaruh positif terhadap Nilai Perusahaan (PBV) perusahaan manufaktur sektor Basic Industry and Chemicals di Bursa Efek Indonerisa periode 2011-2014; Variabel Ukuran Perusahaan berpengaruh positif terhadap Nilai Perusahaan (PBV) perusahaan manufaktur sektor Basic Industry and Chemicals di Bursa Efek Indonerisa periode 2011-2014.

\section{DAFTAR RUJUKAN}

Alivia, Natasha Rizki., Analisis Faktor-faktor yang Mempengaruhi Nilai Perusahaan (Studi Pada Perusahaan Manufakturyang Listed di BEI Tahun 2008-2011), Universitas Diponegoro, Semarang

Anzlina, Corry Winda., 2013, Pengaruh Tingkat Likuiditas,Solvabilitas, Aktivitas, dan Profitabilitas Terhadap Nilai Perusahaan Pada Perusahaan
Real Estate dan Property di BEI tahun 2006-2008, Jurnal Ekonomi Vol 16No 2, April 2013 Fakultas Ekonomi Universitas Sumatera Utara

Arief Sugiono, 2009, Manajemen Keuangan, PT Gramedia Widiasarana Indonesia, Jakarta

Arthur, J. keown, John, D. Martin, J. William Petty, David F, Scott JR, 2008, Manajemen Keuangan, Edisi Kesepuluh, PT Macanan Jaya Cemerlang, Jakarta

Astuti,Dewi., 2004, Manajemen Keuangan Perusahaan,Ghalia Indonesia, Jakarta

Brigham, E.F dan Houston, 2011, Dasardasar Manajemen Keuangan, Edisi Sepuluh, Alih Bahasa Ali Akbar

Daniati, Ninna dan Suhairi., 2006, Pengaruh Kandungan Informasi Komponen Laporan Arus Kas, Laba Kotor dan Size Perusahaan terhadap Expected Return Saham, Simposium Nasional Akuntansi IX, Padang

Dewi, 2013, Pengaruh Struktur Modal, Profitabilitas dan Ukuran Perusahaan terhadap Nilai Perusahaan, E-jurnal Akuntansi, ISSN 2302-8556, Volume 4 No 2 Hal 358-372, Universitas Udayana

Dharmastuti,Fara., 2004, Analisis Pengaruh Faktor-faktor Keuangan Terhadap Harga Saham Perusahaan Go Publik di BEJ, Jurnal Manajemen Vol 1 No. 1, Fakultas Ekonomi, Universitas Atmajaya, Jakarta

Faisal, Irwin.,2015, Analisis Pengaruh Return On Asset, Debt To Equity Ratio,Total Asset Turn Over, Earning Per Share,Price Earning Ratio, dan Current Ratio Terhadap Return Saham Pada Perusahaan Otomotif 
Yang Terdaftar Di Bursa Efek Indonesia, USU,Medan

Ghozali, Imam., 2011, Aplikasi Analisis Multivariate dengan Program IBM SPSS19, Badan Penerbit Universitas Diponegoro, Semarang

Harahap, Sofyan Syafri, 2008, Analisis Kritis atas Laporan Keuangan, PT Raja Grafindo Persada, Jakarta

Horne, James C Vand dan John M Wachowcz Jr.,2012, Prinsp-prinsip Manajemen Keuangan (Edisi 13), Salemba Empat, Jakarta

Husnan, Suad., 2005, Dasar-dasar Teori Protofolio \& Analisis Sekuritas, Edisi 4,UPP AMP YKPN, Yogyakarta

Husnan, Suad dan Enny Pudjiastuti, 2007, Manajemen Keuangan, Edisi Kelima, UPP AMP YKPN, Yogyakarta

Jogiyanto, Hartono., 2008, Teori Portofolio Dan Analisis Investasi, BPFE, Yogyakarta

Kasmir, 2008, Analisis Laporan Keuangan, Raja Grafindo Persada, Jakarta.

Kusmayadi, Dedi., 2008, Analisis Profit Margin, Total Asset Turnover, dan Equity Multiplier Terhadap Return on Equity, Jurnal Ichsan Gorontalo, Vol 3 No 4, November 2008-Januari 2009

Margono, 2008, Metodologi Penelitian Pendidikan,Rineka Cipta, Jakarta

Hanaf, Mamduh M dan Abdul Halim, 2009, Analisis Laporan Keuangan, UPP AMP KPN, Yogyakarta

Nasution, Ihsan Harfani., 2014, Pengaruh Current Ratio (CR), Longterm Debt To Equity Ratio (LtDER), Total Asset Turnover (TATO), Return On Asset (ROA) terhadap Harga Saham Pada

Jurnal Daya Saing
Perusahaan Real Estate dan Property Yang Terdaftar di BEI Tahun 20102012,USU, Medan

Nugroho,Wahyudi Asto, 2012, Pengaruh Profitabilitas, Likuiditas dan Leverage Terhadap Nilai Perusahaan Studi Pada Perusahaan Sektor Manufaktur di Bursa Efek Indonesia Periode 2008-2011, Studi Magister Manajemen, Universitas Muhammadiyah, Surakarta

Salvatore, Dominick., terjemahan Haris Munandar, 2007, Ekonomi Internasional, Erlangga, Jakarta

Santoso, Singgi., 2012, Statistik Multivariat Konsep dan Aplikasi dengan SPSS, PT Elex Media Komputindo, Jakarta

Sartono, Agus., 2010, Manajemen Keuangan Teori dan Aplikasi, Edisi keempat, BPFE, Yogyakarta

Sudarmadji, Ardi Murdoko dan Lana Sularto, 2007, Pengaruh Ukuran Perusahaan,Profitabilitas,Leverage dan Tipe Kepemilikan Perusahaan terhadap Luas Voluntary Discloure Laporan Keuangan Tahunan, Proceeding PESAT, Volume 2

Sugiyono, 2012, Metode Penelitian Bisnis, CV Alfabeta, Bandung

Sukaenah, 2015, Pengaruh Earning Per Share (EPS),Ukuran Perusahaan, Profitabilitas, Leverage, dan Sales Growth Terhadap Nilai Perusahaan Pada Industri Makanan dan Minuman Yang Terdaftar di Bursa Efek Indonesia, Journal Of Accounting, Volume 1 No 1 Februari 2015, Universitas Pandanaran Semarang

Suliyanto, 2011, Ekonometrika Terapan: Teori dan Aplikasi dengan SPSS, ANDI, Yogyakarta

p.ISSN: 2407-800X e.ISSN: 2541-4356 
Sujoko dan Soebiantoro,U.,2007, Pengaruh

Struktur Kepemilikan Saham,Leverage, Faktor Intern dan Faktor Ekstern terhadap Nilai Perusahaan, Jurnal Manajemen dan Kewirausahaan, Vol 9,47

Tjiptono, Darmadji dan Hendi M Fakhrudin., 2006, Pasar Modal di Indonesia : Pendekatan Tanya Jawab, Salemba Empat, Jakarta

Wedana, Nyoman Adi Putra, 2014, Pengaruh Faktor Fundamental Pada Nilai Perusahaan Sektor Telekomunikasi di Bursa Efek Indonesia, E-Jurnal Akuntansi Universitas Udayana, Vol 8 No 3, Hal 385-407

Yulistiana, Ana.,2009, Pengaruh Earning Per Share (EPS), Return on Asset (ROA), dan Arus Kas Operasi, terhadap Nilai Perusahaan (Pada Perusahaan Yang Terdaftar di Jakarta Islamic Index Tahun 2004-2006), Program Stud Keuangan Islam, Fakultas Syariah, UIN SUSKA, Yogyakarta

http://www.idx.co.id/ IDX - Indonesia Stock Exchange - Bursa Efek Indonesia 